\title{
$\begin{array}{lllllllll}\text { I } & \mathrm{N} & \mathrm{S} & \mathrm{T} & \mathrm{I} & \mathrm{T} & \mathrm{U} & \mathrm{T} & \mathrm{E}\end{array}$
}

\section{The State of Working New Hampshire 2007}

\author{
A L L I S ON CHURILLA
}

$\mathrm{T}$ The national economy recovered relatively quickly from the 2001 recession, with the economy growing at a rate that averaged just below 3 percent a year. During this period, growth in national productivity has been very strong, even outpacing the growth in national productivity in the boom period of the last half of the 1990s. However, workers in New Hampshire and in the nation have not had equivalent growth in their wages, real income, and employment.

The period since the 2001 recession has been characterized as a "jobless recovery." New Hampshire has had only 3 percent employment growth since 2000. This slow growth follows a five-year period of 15 percent job growth in the state between 1995 and 2000. Job growth was also greater during the previous economic recovery of the early 1990s, with 6 percent growth between 1990 and 1995 .

This issue brief updates employment figures and trends documented in the State of Working New Hampshire 2006. By and large, there were only small changes in employment over the past year. Where it is useful for perspective, the report includes references to employment trends in New Hampshire since 1990, a time period that provides perspective on state-level economic trends following two recessions and two distinct periods of economic expansion. ${ }^{1}$ This brief is produced in cooperation with the Economic Policy Institute (EPI).

\section{Labor Force Participation Remains High but Continues to Decline}

New Hampshire had a 71 percent labor force participation rate in 2006, higher than both national and New England participation rates (66 percent and 68 percent, respectively). Compared to other states in the region, New Hampshire also had the lowest unemployment and underemployment rates in $2006 .^{2}$

Even though labor force participation remains high in New Hampshire, the participation rate has dropped 2 percentage points since 2000 when it stood at 73 percent. Decline in the state rate is largely related to lower labor force participation among young workers, male workers, and workers with a high school degree or less.

Underemployment rose by 2 to 3 percentage points for these three groups of workers between 2000 and 2006; unemployment rose by 1 percentage point for male workers and workers with a high school degree or less. In part, lower labor force participation rates for these two groups of workers may be associated with substantial job losses in the manufacturing, transportation and utilities, and information sectors.

\section{Continued Job Growth with Losses in Specific Industries}

New Hampshire has experienced a net gain of 17,000 jobs since 2000, representing a 3 percent increase between 2000 and 2006. This rate of growth mirrors national job growth (up 3 percent) and outpaces regional job growth (down 1 percent) over the same six-year time period. The New England region's decline largely reflected slow economic recovery in Massachusetts, the state with nearly half of the region's employment in 2006.

In the early 2000s, job growth in New Hampshire has been led by the education and health services industry. This is now the largest industry in New Hampshire, comprising 16 percent of all jobs in the state. In 2000, the industry was the third largest in the state, comprising 13 percent of jobs. This means that, between 2000 and 2006, one-third of jobs gained in the state were in this rapidly growing sector. Positive growth in seven other industries added an additional 32,000 jobs over this six year time period, for a gross gain of 48,200 jobs in New Hampshire since 2000.

There are continued declines in manufacturing, the industry that has been hardest hit in terms of job loss. In 2000, manufacturing was the largest industry in New Hampshire, employing over 100,000 workers and comprising 16 percent of all jobs in the state. By 2006, manufacturing employed 25,000 fewer workers and dropped to the fourth largest industry in the state. ${ }^{3}$ Job losses in manufacturing have been particularly hard on some counties. Three counties experienced overall job loss between 2000 and 2005: Sullivan (down 4 percent), Coos (down 3 percent), and Strafford 
Figure 1. Absolute Change in Employment by Industry in New Hampshire, 2000-2006

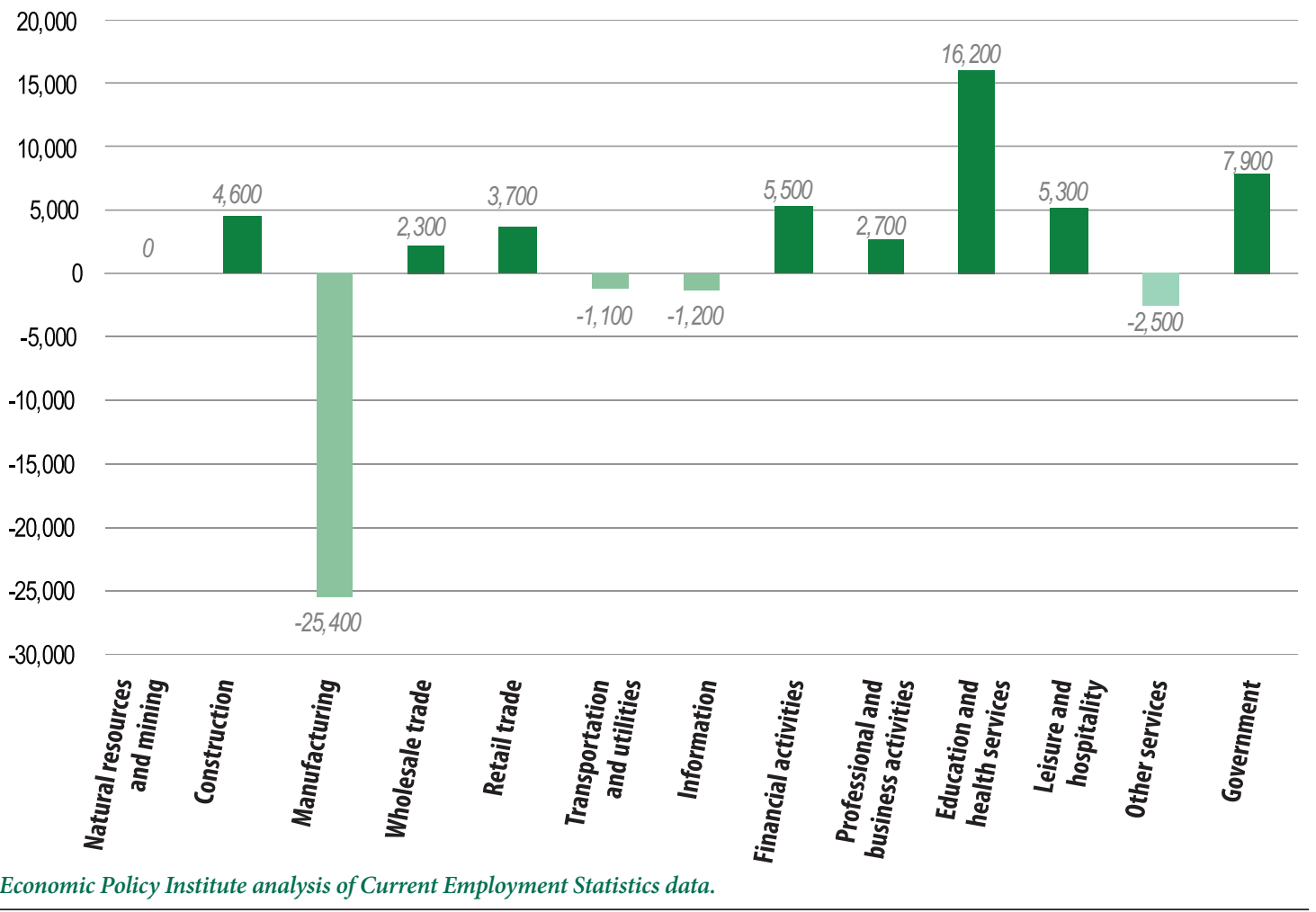

(down 1 percent). ${ }^{4}$ In each of these counties, a considerable portion of job loss was attributable to declines in paper, metal, machinery, and/or wood manufacturing.

\section{Wage Growth Not Keeping Pace with Living Expenses}

National productivity increased by 17 percent between 2000 and 2006, but the national median wage increased by 3 percent over the same time period. ${ }^{5}$ In New Hampshire, workers fared better. Median wage growth was steeper than the national figure, with median wages up 8 percent since 2000. An exclusive focus on median wage growth conceals wage inequality in the state. Low-wage workers' earnings have increased 3 percent since 2000, compared to 8 percent wage growth for middle-wage workers and 10 percent wage growth for high-wage workers.

Wage growth in New Hampshire has not kept pace with national productivity, nor has it kept pace with rising cost of living in the state. Since 2000, working families in New Hampshire have seen median monthly rental payments increase by 19 percent and median mortgage payments increase by 21 percent. $^{6}$ This means that, even for high-wage workers, growth in housing costs outpaced personal wage growth between 2000 and 2006 .

In addition to housing, working families have other basic expenses, including food, transportation, child and health care, and other household expenses. Researchers in the state estimate that working parents need to earn an hourly wage of $\$ 16.27$ or higher to meet their family’s basic living expenses. ${ }^{7,8}$
In 2006, more than 40 percent of workers in New Hampshire earned an hourly wage below this threshold. Adults without children are estimated to need an hourly wage of $\$ 10.69$ per hour to meet expenses; more than 20 percent of workers in the state earned a wage below this level in 2006.

\section{Summary}

Relative to the nation and other states in the region, New Hampshire workers continue to fare well on many measures of economic well-being. But it is clear that New Hampshire workers have not benefited to the same extent they did during the economic expansion of the mid-1990s. Labor force participation remains high in the state, but participation rates continue to decline. Workers' wages continue to rise, yet wage growth is not keeping pace with rising living expenses. New Hampshire workers cope with rising housing costs and, for some, an inability to meet basic living expenses. Finally, job growth remains positive, but growth is slow compared to the economic recovery of the 1990s.

Labor force trends in New Hampshire are largely positive, suggesting that a large portion of workers and their families are faring well in this economic recovery. But New Hampshire workers-especially workers with lower levels of education and workers in particular industries-are being hit by the jobless recovery that characterizes the period since 2001. Careful consideration is necessary to ensure that New Hampshire workers who contribute to the growing economy are seeing corresponding wage benefits. 
Table 1. Growth in Average Monthly Private Sector Employment in New Hampshire Counties, 1990-2005

\begin{tabular}{l|c|c|c}
\hline & $\mathbf{1 9 9 0 - 1 9 9 5}$ & $\mathbf{1 9 9 5 - 2 0 0 0}$ & $\mathbf{2 0 0 0 - 2 0 0 5}$ \\
\hline BELKNAP COUNTY & $9 \%$ & $17 \%$ & $\mathbf{2} \%$ \\
\hline CARROLL COUNTY & $9 \%$ & $\mathbf{1 6} \%$ & $4 \%$ \\
\hline CHESHIRE COUNTY & $5 \%$ & $4 \%$ & $-3 \%$ \\
\hline COOS COUNTY & $-5 \%$ & $15 \%$ & $4 \%$ \\
\hline GRAFTON COUNTY & $8 \%$ & $16 \%$ & $0 \%$ \\
\hline HILLSBOROUGH COUNTY & $3 \%$ & $15 \%$ & $3 \%$ \\
\hline MERRIMACK COUNTY & $13 \%$ & $24 \%$ & $5 \%$ \\
\hline ROCKINGHAM COUNTY & $14 \%$ & $1 \%$ & $-1 \%$ \\
\hline STRAFFORD COUNTY & $18 \%$ & $1 \%$ & $-4 \%$ \\
\hline SULLIVAN COUNTY & $7 \%$ & $15 \%$ & $2 \%$ \\
\hline
\end{tabular}

Source: County employment figures are based on author's analysis of data from the New Hampshire Department of Employment Security Economic Statistics; state employment figures are based on Economic Policy Institute analysis of Current Population Survey data.

\section{Data Used in this Report}

Unless otherwise noted, figures cited in this report are based on the Economic Policy Institute's analysis of Current Employment Statistics and Current Population Survey data. The Current Employment Statistics program surveys a sample of more than 400,000 business establishments and government agencies to provide industry estimates of job growth, hours, and wages. Data are collected as part of a joint effort between state employment security agencies and the Bureau of Labor Statistics. The Current Population Survey program surveys a nationally representative sample of 50,000 households and individuals in those households to provide demographic and employment information on the United States population. The survey is conducted by the U.S. Bureau of the Census for the Bureau of Labor Statistics. Except when noted otherwise, dollar amounts were adjusted for inflation to 2006 dollars.

\section{A U T H O R}

Allison Churilla is a Policy Fellow at the Carsey Institute and a Ph.D. Candidate in the Department of Sociology at the University of New Hampshire (allison.churilla@unh.edu).

\section{A C K N O W L E D G E M E N T S}

The author would like to thank Cynthia Duncan, Ross Gittell, Curt Grimm, Ken Johnson, and Kristin Smith for their thoughtful comments on earlier versions of this issue brief. This work was supported by the New Hampshire Charitable Foundation, its Durum Fund, and other funders. Responsibility for the analysis lies with the Carsey Institute.

\section{Endnotes}

${ }^{1}$ According to the National Bureau of Economic Research, the recession of the early 1990s took place from July 1990 to March 1991; the recession of the early 2000s took place between March and November 2001. For more information on business cycle contractions, see http://www.nber.org/cycles.html.

${ }^{2}$ Unemployed workers include those willing and able to work that looked for work in the four weeks preceding data collection. Underemployed workers include unemployed workers, those working part-time that desire full-time employment, "discouraged" workers that have given up seeking employment, and "marginally attached" workers that are not currently searching but desire employment and have looked for work in the previous 12 months.

${ }^{3}$ In 2006, the top three industries in New Hampshire were education and health services (16 percent of jobs), retail trade (15 percent), and government (14 percent).

${ }^{4}$ At the time of publication, county-level data was not yet available for all four quarters of 2006.

${ }^{5}$ National productivity is a measure of the national output of goods and services per hour of work. The computation of growth in national productivity is based on the author's analysis of data from the Bureau of Labor Statistics.

${ }^{6}$ Housing costs are based on author's analysis of data from the 2000 Public Use Microdata Sample (PUMS) and the 2006 American Community Survey (ACS). Figures cited reflect growth in median housing payments between 1999 and 2005 for families with at least one adult employed in the labor force.

${ }^{7}$ Kenyon, Daphne. 2006. "New Hampshire's Basic Needs and Livable Wage 2006.” Concord, NH: UNH Office of Economic Initiatives and North Country Council, Inc.

${ }^{8}$ Livable wage estimates are lower if two parents are working (\$10.36 to \$11.99 per hour). Estimates were in 2005 dollars in the original report; for comparability, author adjusted dollar amounts to 2006 dollars. 


\section{$\triangle$ UNIVERSITY \\ of NEW HAMPSHIRE}

\section{CARSEY}

Building knowledge for families and communities

in the 21 st Century.

The Carsey Institute at the University of New Hampshire conducts independent, interdisciplinary research and communicates its findings to policymakers, practitioners and the general public.

Huddleston Hall

73 Main Street

Durham, NH 03824

(603) $862-2821$

\section{www.carseyinstitute.unh.edu}

This brief is part of a series of Carsey Institute Reports on Changes in New England. 